\title{
PROJEKTI ZELENA KNJIŽNICA \\ I ŽIVJETI ZDRAVO U GRADSKOJ KNJIŽNICI „JURAJ ŠIŽGORIĆ““ ŠIBENIK
}

\author{
THE PROJECTS “GREEN LIBRARY” \\ AND “LIVING HEALTHY”IN THE CITY LIBRARY \\ "JURAJ ŠIŽGORIĆ” IN ŠIBENIK
}

\begin{abstract}
Melinda Grubišić Reiter
Gradska knjižnica „Juraj Šižgorić“ Šibenik

mgrubisic-reiter@knjiznica-sibenik.hr
\end{abstract}

\author{
UDK / UDC 027.3:502/504(497.5 Šibenik) \\ Stručni rad / Professional paper \\ Primljeno / Received: 2. 11. 2018. \\ Prihvaćeno / Accepted: 8. 2. 2019.
}

\section{Sažetak:}

Cilj. Cilj je ovoga rada ${ }^{1}$ upoznati javnost, prije svega knjižničarsku zajednicu, s aktivnostima/programima (predavanjima, tribinama, predstavljanjima knjiga, izložbama i radionicama) koje su Knjižničarsko društvo Šibenik i Gradska knjižnica „Juraj Šižgorić" Šibenik realizirali u posljednje dvije godine u okviru projekata Zelena knjižnica i Živjeti zdravo te istaknuti njihovo značenje kako za određene društvene skupine tako i za društvo u cjelini.

Metodologija. Iznesene su, kronološkim redom i prema temama koje je provedba projekata obuhvatila, aktivnosti Knjižnice u sklopu projekata Zelena knjižnica i Živjeti zdravo. Kao izvor podataka poslužili su arhiva događanja u Gradskoj knjižnici „Juraj Šižgorić" Šibenik i različite mrežne stranica na kojima se mogu naći podaci o tim projektima.

\footnotetext{
1 Rad je prezentiran na 43. Skupštini Hrvatskoga knjižničarskog društva održanoj u Opatiji od 10. do 13. listopada 2018.
}

Vjesnik bibliotekara Hrvatske 62, 1(2019), 307-325

ISSN 0507-1925

(C) VBH 2018. 
Rezultati. U radu je dan pregled aktivnosti/programa koje su Knjižničarsko društvo Šibenik i Gradska knjižnica „Juraj Šižgorić“ Šibenik tijekom posljednje dvije godine organizirali u okviru projekata Zelena knjižnica i Živjeti zdravo. Poseban naglasak stavljen je na ciljeve UN-ove Agende 2030. Prikazani su različiti oblici edukacije korisnika, osobito djece i mladih, ali i osoba starije životne dobi, o važnosti očuvanja tjelesnog i mentalnog zdravlja, usvajanju navika pravilne prehrane i tjelesne aktivnosti, potrebi zaštite prirode i održivom razvoju.

Društveni značaj. Teme kojima se projekti Zelena knjižnica i Živjeti zdravo bave, kao što su očuvanje okoliša i održivi razvoj, važne su jer je riječ o preduvjetima za bolji život pojedinaca, ali i svijeta u cjelini.

Originalnost. Prikazane su neke od aktivnost, npr. dječje likovne radionice ili likovni natječaji u kojima sudjeluju školska djeca, kao jedinstveni načini na koje se ekološka tematika može približiti pojedinim skupinama korisnika.

Ključne riječi: Ekologija, Gradska knjižnica „Juraj Šižgorić“ Šibenik, održivi razvoj, projekt Živjeti zdravo, Zelena knjižnica

\section{Abstract}

Objective. The objective of this paper is to inform the public and the library community about the activities and lectures, presentations of books, exhibitions and workshops that the Šibenik Library Association and the "Juraj Šižgorić" City Library Šibenik have realized in the last two years, within the projects "Green Library" and "Healthy Living", and to highlight their significance for certain social groups as well as for the whole society.

Methodology. The activities of the Library, within the "Green Library" and "Healthy Living" projects, have been presented in the chronological order and according to the themes covered by the implementation of the projects. The data sources were the archives of the events in the "Juraj Šižgorić" City Library in Šibenik and various web pages that present relevant information on these projects.

Results. The paper presents an overview of the activities and programs that Šibenik Library Association and the "Juraj Šižgorić" City Library Šibenik have organised during the last two years within the framework of the "Green Library" and "Health Living" projects. Special emphasis is given to the goals of the UN Agenda 2030. Various forms of user education are presented, especially for children and young people, as well as for older persons, the importance of preserving physical and mental health, the adoption of habits of proper nutrition and physical activity, nature conservation and sustainable development.

Social implications. The topics that the "Green Library" and "Healthy Living" projects promote, such as preserving the environment and sustainable development, are 
important because they are the preconditions for a better life for individuals and also for the world as a whole.

The originality/value.Some of the activities, such as children's art workshops or art competitions are presented as a unique way to bring the ecological themes closer to individual or groups of users.

Keywords: City Library “Juraj Šižgorié” Šibenik, ecology, Green Library, Healthy Lifestyle, sustainable development

\section{Uvod}

Gradska knjižnica „Juraj Šižgorić“ Šibenik prva u Hrvatskoj počela je provoditi program zelene knjižnice prema koncepciji projekta Zelena knjižnica Društva bibliotekara Istre još 2012., godinu dana nakon njegova pokretanja. Prva aktivnost koju je poduzela bila je projekcija dokumentarnog filma Annie Leonard Priča o stvarima (The Story of Stuff) iz 2007. godine u multimedijskoj dvorani Knjižnice. ${ }^{2}$ U Knjižnici su od tada održane brojne aktivnosti ekološkog sadržaja za djecu i odrasle, među kojima su predavanja i tribine o permakulturi, zelenoj energiji, biološkoj raznovrsnosti i pravilnoj prehrani, izložbe, radionice i projekcije filmova itd. $^{3}$

\section{Održivi razvoj}

Održivi razvoj znači zaštitu i očuvanje prirodnog okoliša planeta te promicanje pravednog društva i gospodarske jednakosti unutar država i između njih. ${ }^{4}$ Riječ razvoj odnosi se na gospodarski rast, a druga riječ, održivost, znači rad, proizvodnju i potrošnju unutar ekoloških granica, ali uz jamčenje nastavka gospodarskog rasta kao načina borbe protiv siromaštva, bolesti i drugih teškoća. ${ }^{5}$

Godine 1972., na prvoj konferenciji UN-a o zaštiti okoliša u Stockholmu, prvi je put iznesena ideja o održivom razvoju. Potpuna pozornost bila je posvećena ekološkoj održivosti, a tek malo političkim, ekonomskim i društvenim pitanjima. ${ }^{6}$ Konferencija o okolišu i razvoju UN-a u Rio de Janeiru 1992. godine prihvatila je deklaraciju o okolišu i razvoju i Agendu 21, koja daje preporuke za održivo upravljanje zemljišnim, vodnim i šumskim resursima. Osnovno značenje Agende 21 jest

2 Izvješće o radu Gradske knjižnice „Juraj Šižgorić“ Šibenik u 2012. godini. [citirano: 2018-1025]. Dostupno na: http://www.knjiznica-sibenik.hr/dokum/Izvjesce_o_radu_knjiznice_u_2012.pdf.

3 Gradska knjižnica „Juraj Šižgorić“. Arhiva događanja. [citirano: 2018-10-25]. Dostupno na: http://www.knjiznica-sibenik.hr/arhiva_d.html.

4 Blewitt, J. Razumijevanje održivog razvoja. Zagreb: Naklada Jesenski i Turk, 2017. Str. 34.

5 Isto, str. 62.

6 Herceg, N. Okoliš i održivi razvoj. Zagreb: Synopsis, 2013. Str. 255. 
da se fokusira na političke, ekonomske i društvene probleme održivog razvoja, a ne samo na tradicionalnu agendu očuvanja okoliša. Utemeljena je Komisija za održivi razvoj i donesena deklaracija kojom je definiran pojam održivog razvoja. ${ }^{7}$

Strategija UNECE-a (United Nations Economic Commission for Europe) za obrazovanje za održivi razvoj donesena je 2005. godine u Vilniusu, a govori o uvođenju obrazovanja za održivi razvoj u formalne obrazovne sustave i u neformalno obrazovanje. ${ }^{8}$

Na konferenciji UN-a o održivom razvoju održanoj u New Yorku u rujnu 2015. usvojena je, nakon tri godine intenzivnih pregovora i konzultacija s brojnim dionicima, UN-ova Agenda 2030 za održivi razvoj. Riječ je o ključnoj globalnoj političkoj platformi za rješavanje brojnih izazova današnjice u njihovim međusobno isprepletenim gospodarskim, socijalnim, ekološkim i političko-sigurnosnim dimenzijama. Glavnu okosnicu Agende predstavlja sedamnaest ciljeva održivog razvoja koje su dogovorili svjetski čelnici, a ciljna je godina petnaestogodišnjeg programa $2030 .{ }^{9}$

Ciljevi održivog razvoja:

Cilj 1. Iskorijeniti sve oblike siromaštva svuda u svijetu

Cilj 2. Iskorijeniti glad, postići sigurnost hrane i poboljšanu ishranu te promicati održivu poljoprivredu

Cilj 3. Osigurati zdrav život i promicati blagostanje za ljude svih generacija

Cilj 4. Osigurati uključivo i pravedno kvalitetno obrazovanje te promicati mogućnosti cjeloživotnog učenja za sve

Cilj 5. Postići rodnu ravnopravnost i osnažiti sve žene i djevojčice

Cilj 6. Osigurati pristup pitkoj vodi za sve, održivo upravljati vodama te osigurati higijenske uvjete za sve

Cilj 7. Osigurati pristup pouzdanoj, održivoj i suvremenoj energiji po pristupačnim cijenama za sve

Cilj 8. Promicati kontinuiran, uključiv i održiv gospodarski rast, punu i produktivnu zaposlenost i dostojanstven rad za sve

Cilj 9. Izgraditi prilagodljivu infrastrukturu, promicati uključivu i održivu industrijalizaciju i poticati inovativnost

Cilj 10. Smanjiti nejednakosti unutar država i između njih

\footnotetext{
Isto, str. 256.

8 Isto, str. 258.

9 Novi izazov: globalni ciljevi održivog razvoja do 2030. Zagreb: ODRAZ, 2016. Str. 1. Dostupno i na: http://odraz.hr/media/291518/globalni\%20ciljevi\%20odrzivog\%20razvoja\%20do\%20 2030_web.pdf. [citirano: 2018-10-25].
} 
Cilj 11. Učiniti gradove i naselja uključivim, sigurnim, prilagodljivim i održivim

Cilj 12. Osigurati održive oblike potrošnje i proizvodnje

Cilj 13. Poduzeti hitna djelovanja u borbi protiv klimatskih promjena i njihovih posljedica

Cilj 14. Očuvati i održivo koristiti oceane, mora i morske resurse za održiv razvoj

Cilj 15. Očuvati, ponovno uspostaviti i promicati održivo korištenje kopnenih ekosustava, održivo upravljati šumama, suzbiti dezertifikaciju, zaustaviti degradaciju tla te spriječiti uništavanje biološke raznolikosti

Cilj 16. Promicati, u svrhe održivog razvoja, miroljubiva i uključiva društva, osigurati pristup pravosuđu za sve i izgraditi učinkovite, odgovorne i uključive institucije na svim razinama

Cilj 17. Ojačati načine provedbe te učvrstiti globalno partnerstvo za održivi razvoj. $^{10}$

Republika Hrvatska od samog je početka aktivno sudjelovala u procesu donošenja dokumenata važnih za globalni održivi razvoj u svim relevantnim tijelima UN-a i Europske unije. Nakon Milenijske deklaracije, koju su u rujnu 2000. godine donijele države članice UN-a, obvezavši se da će maksimalno ispuniti osam ključnih razvojnih ciljeva, Republika Hrvatska preuzela je tih osam ciljeva kao nacionalne ciljeve, pridodavši im i trideset jedan podcilj koji odgovara specifičnim razvojnim okolnostima i uvjetima u našoj zemlji. ${ }^{11}$ Zakonom o zaštiti okoliša iz 2007. određena je „Strategija održivog razvitka Republike Hrvatske“12, u kojoj se također naglašava potreba intenzivnog i sustavnog informiranja javnosti u svrhu podizanja svijesti građana i poticanja na sudjelovanje.

Vlada Republike Hrvatske u siječnju 2018. godine donijela je Odluku o osnivanju Nacionalnog vijeća za održivi razvoj, koje ima zadatak pratiti i koordinirati provedbu globalnih ciljeva održivog razvoja. ${ }^{13}$ Odlučeno je da će fokus biti na provedbi šesnaest ciljeva održivog razvoja koji su nacionalnog karaktera, a posljednji, sedamnaesti cilj, vezan uz međunarodnu suradnju, već je ranije bio dogovoren međunarodnim ugovorima. Ciljevi su sljedeći:

\footnotetext{
10 Isto, str. 8-24.

11 Isto, str. 5.

12 Strategija održivog razvitka Republike Hrvatske. // Narodne novine 30, 658(2009). [citirano: 20 18-10-25]. Dostupno i na: http://narodne-novine.nn.hr/clanci/sluzbeni/2009_03_30_658.html. 13 Održivi razvoj. [citirano: 2018-10-25]. Dostupno na:.html https://www.mzoip.hr/hr/klima/ odrzivi-razvoj.
} 


\begin{tabular}{|c|c|}
\hline Cilj 1 & Iskorijeniti siromaštvo svugdje i u svim njegovim oblicima \\
\hline Cilj 2 & $\begin{array}{l}\text { Iskorijeniti glad, osigurati dostatne količine hrane i bolju prehranu te } \\
\text { promicati održivu poljoprivredu }\end{array}$ \\
\hline Cilj 3 & $\begin{array}{l}\text { Osigurati zdrav život i promicati blagostanje svih ljudi svih starosnih } \\
\text { skupina }\end{array}$ \\
\hline Cilj 4 & $\begin{array}{l}\text { Osigurati uključivo i pravedno obrazovanje i promicati prilike za } \\
\text { cjeloživotno učenje svim ljudima }\end{array}$ \\
\hline Cilj 5 & Postići ravnopravnost spolova i osnažiti sve žene i djevojčice \\
\hline Cilj 6 & Osigurati dostupnost i održivo upravljanje vodama te zdravstvene uvjete za sve \\
\hline Cilj 7 & Osigurati financijski dostupnu, pouzdanu, održivu i modernu energiju za sve \\
\hline Cilj 8 & $\begin{array}{l}\text { Promicati ravnomjeran, uključiv i održiv gospodarski rast, punu i } \\
\text { produktivnu zaposlenost i dostojan posao za sve }\end{array}$ \\
\hline Cilj 9 & $\begin{array}{l}\text { Izgraditi otpornu infrastrukturu, promicati uključivu i održivu } \\
\text { industrijalizaciju i poticati inovacije }\end{array}$ \\
\hline Cilj 10 & Smanjiti nejednakosti unutar zemalja i među zemljama \\
\hline Cilj 11 & $\begin{array}{l}\text { Učiniti gradove i ljudska naselja uključivima, sigurnima, otpornima i } \\
\text { održivima }\end{array}$ \\
\hline Cilj 12 & Osigurati održive obrasce potrošnje i proizvodnje \\
\hline Cilj 13 & $\begin{array}{l}\text { Poduzeti hitne mjere u borbi protiv klimatskih promjena i njihovih } \\
\text { negativnih utjecaja (priznajući da je UNFCCC glavni međunarodni, } \\
\text { međuvladin forum za pregovaranje o globalnom odgovoru na klimatske } \\
\text { promjene) }\end{array}$ \\
\hline Cilj 14 & $\begin{array}{l}\text { Očuvati i održivo koristiti oceane, mora i morske resurse za održivi } \\
\text { razvoj }\end{array}$ \\
\hline Cilj 15 & $\begin{array}{l}\text { Štititi, obnavljati i promicati održivo korištenje zemaljskih ekosustava, } \\
\text { održivo upravljati šumama, boriti se protiv dezertifikacije, zaustaviti } \\
\text { i obrnuti proces degradacije zemljišta te zaustaviti gubitak biološke } \\
\text { raznolikosti }\end{array}$ \\
\hline Cilj 16 & $\begin{array}{l}\text { Promicati mirna i uključiva društva za održivi razvoj, osigurati pristup } \\
\text { pravdi za sve i izgraditi učinkovite, odgovorne i uključive institucije na } \\
\text { svim razinama. }{ }^{14}\end{array}$ \\
\hline
\end{tabular}

14 Odluka o osnivanju Nacionalnog vijeća za održivi razvoj.// Narodne novine 7, 188(2018). [citirano: 2018-10-25]. Dostupno na: https://narodne-novine.nn.hr/clanci/sluzbeni/full/2018_01_7_188. html. 


\section{Važnost doprinosa knjižnica održivom razvoju}

IFLA (Međunarodni savez knjižničarskih društava i ustanova) u Izjavi o knjižnicama i razvitku 36 (2013.) $)^{15}$ naglašava upravo jedinstvenu ulogu knjižnica kao razvojnih partnera u pružanju pristupa informacijama u svim oblicima, kao i pružanju usluga i programa koji zadovoljavaju potrebe korisnika u društvu koje se ubrzano mijenja i postaje sve složenije. IFLA poziva sve subjekte društva, i pojedince i skupine, da posvuda u svijetu prepoznaju i priznaju knjižnice kao pouzdane ustanove koje podupiru provedbu programa održivog razvoja.

IFLA u svojoj „Izjavi o knjižnicama i razvitku“ naglašava da knjižnice imaju prirodnu ulogu pružanja pristupa informacijskim sadržajima i uslugama koje podupiru održivi razvoj te poziva donositelje odluka da ih prepoznaju kao pouzdane ustanove za provedbu zelenih programa jer mogu dati znatan doprinos rješavanju problema održivosti na razini cijele zajednice. To se podjednako odnosi na sve vrste knjižnica, s tim da narodne knjižnice imaju prednost jer su one javno dostupni prostori otvoreni za korisnike svih dobnih skupina. ${ }^{16}$

Knjižnice su, zajedno s drugim informacijskim posrednicima, istaknute kao mjesta koja imaju sposobnosti i resurse da pružanjem informacija i povezivanjem zainteresiranih strana pomognu vladama, ustanovama i pojedincima u upravljanju vlastitim razvojem, odnosno u donošenju odgovornih odluka važnih za postizanje održive budućnosti.

Na prošlogodišnjem Svjetskom knjižničarskom i informacijskom kongresu, održanom od 19. do 25. kolovoza 2017. u Wrocławu, u Poljskoj, i 83. generalnoj skupštini IFLA-e, održanoj u sklopu Kongresa, među temama izlaganja bile su i „Opredijeljenost knjižnica za UN Agendu 2030 za održivi razvoj - ekološka održivost i knjižnice“" (Libraries' Commitment to the UN Agenda 2030 for Sustainable Development - Environmental Sustainability and Libraries) i „Više od zelenoga - održivost u praksi““ (More than Green - Sustainability of Practice). ${ }^{17}$

IFLA-ina Radna skupina za okoliš, održivost i knjižnice (Environmental, Sustainability and Libraries Special Interest Group) organizirala je dvije sesije predavanja o zelenim knjižnicama.

Ta radna skupina razmatra ulogu čovječanstva u klimatskim promjenama te pojam održivog razvoja promatra kao jedan od osnovnih društvenih problema na globalnoj razini, što znači da on neizravno pogađa i knjižnice. Zelene knjižnice usmjerene su na smanjivanje čovjekova negativnog utjecaja na okoliš te se zalažu

15 IFLA statement on libraries and development. [citirano: 2018-10-25]. Dostupno na: http:// www.ifla.org/publications/ifla-statement-on-libraries-and-development.

16 UNESCO-ov manifest za narodne knjižnice. Dostupno na: http://dzs.ffzg.unizg.hr/text/ UNESCOv_manifest_za_narodne_knjiznice.htm.

17 IFLA World Library and Information Congress. [citirano: 2018-10-25]. Dostupno na:https://2017.ifla.org/. 
za korištenje prirodnih građevinskih materijala i biorazgradivih proizvoda, očuvanje prirodnih resursa (vode, energije, šuma) itd. ${ }^{18}$

Prvi hrvatski projekt koji je programski spojio knjižničarstvo i ekologiju jest projekt Zelena knjižnica koji je u ožujku 2011. godine pokrenulo Društvo bibliotekara Istre u Puli. ${ }^{19}$ Cilj toga projekta jest širenje svijesti i educiranje javnosti o održivom društvu i potrebi zaštite okoliša. U tu svrhu organizirana su stručna predavanja, tribine i predstavljanja knjiga, projekcije dokumentarnih filmova itd., a pokrenut je i portal Zelena knjižnica. Projekt podržavaju Ministarstvo kulture Republike Hrvatske, Grad Pula i Grad Rovinj. Njegovi su korisnici u prvom redu učenici i studenti, a potom i šira javnost. Neka predavanja organizirana u sklopu Zelene knjižnice uključena su u čak tri kolegija na Fakultetu ekonomije i turizma „Dr. Mijo Mirković“ u Puli, od kojih je jedan postdiplomski. S obzirom na to da je projekt jako dobro prihvaćen u Istarskoj županiji i da aktivnosti u sklopu projekta uključuju brojne sudionike i publiku, nadišao je lokalno značenje te je podignut na nacionalnu razinu, odnosno proširio se i u druge županije. Iako su i prije toga projekta Društva bibliotekara Istre mnoge hrvatske knjižnice povremeno organizirale različite aktivnosti vezane uz ekologiju, taj je projekt, kao uzor, oblikovao model knjižničnih zelenih programa i potaknuo razvoj takvih sustavnih i kontinuiranih programa na nacionalnoj razini. ${ }^{20}$

U Nacionalnoj i sveučilišnoj knjižnici 10. prosinca 2015. održan je 15. okrugli stol o slobodnom pristupu informacijama pod nazivom „Knjižnice i održivi razvoj“21, a zatim je u organizaciji Hrvatskog knjižničarskog društva (HKD) 17. i 18. travnja 2018. održana, također u Nacionalnoj i sveučilišnoj knjižnici u Zagrebu, radionica „Uloga knjižnica u provođenju UN-ove Agende 2030. i ciljeva održivog razvoja“22 na kojoj su sudionici imali priliku doznati sve što ih zanima o ciljevima UN-ove strategije održivog razvoja, kao i o planu zagovaranja knjižnica kao partnera u provođenju tih ciljeva. Središnja tema prošlogodišnje

18 Svjetski knjižničarski i informacijski kongres i 83. generalna skupština IFLA-e. [citirano: 2018-10-25]. Dostupno na: http://www.nsk.hr/svjetski-knjiznicarski-i-informacijski-kongres-i-83-generalna-skupstina-ifla-e/.

19 Kraljević, I. Zelena knjižnica: projekt Društva bibliotekara Istre. // Vjesnik bibliotekara Hrvatske 56, 3(2013), 199-204.

20 Dragaš, B. Zelene knjižnice za zelenu pismenost: hrvatsko iskustvo. // Vjesnik bibliotekara Hrvatske 60, 4(2017), 221-241. Dostupno i na: https://www.hkdrustvo.hr/vjesnik-bibliotekara-hrvatske/index.php/vbh/article/view/530. [citirano: 2018-10-25].

${ }^{21}$ 15. okrugli stol o slobodnom pristupu informacijama "Knjižnice i održivi razvoj”. [citirano: 2018-10-25]. Dostupno na: http://www.nsk.hr/15-okrugli-stol-o-slobodnome-pristupu-informacijama-knjiznice-i-odrzivi-razvoj/.

22 Radionica „Uloga knjižnica u provođenju UN-ove Agende 2030. i ciljeva održivog razvoja“ u NSK.. [citirano: 2018-10-25]. Dostupno na: http://www.nsk.hr/radionica-uloga-knjiznica-u-provodenju-un-ove-agende-2030-i-ciljeva-odrzivog-razvoja-u-nsk/. 
skupštine Hrvatskog knjižničarskog društva bio je doprinos knjižnica održivom razvoju Agende 2030.23

Na Skupštini Hrvatskog knjižničarskog društva održanoj u Splitu 15. listopada 2014. ustanovljena je Radna grupa za zelene knjižnice, po uzoru na srodnu IFLA-inu radnu grupu za održivost okoliša i knjižnice. Namjera je te radne grupe da preraste u komisiju, kao viši organizacijski stupanj. Njezino ime poteklo je od projekta Zelena knjižnica, da bi se zadržala tradicija i konotacije koje taj projekt ima u našim lokalnim prilikama.

Radna grupa potaknula je uspostavljanje mreže knjižnica koje su se uključile u postojeći obrazac projekta Zelena knjižnica (www.zk.dbi.hr) s ciljem podizanja svijesti o održivom društvu, edukacije javnosti i potrebe zaštite okoliša kroz knjižnice i knjižničarska društva. Osim toga, radna grupa bavi se i pitanjima energetske učinkovitosti u knjižnicama. ${ }^{24}$

Napravljena je i online anketa koja je preko županijskih matičnih službi proslijeđena svim knjižnicama. Anketa je napravljena s ciljem da se dobije uvid u stanje na terenu radi umrežavanja knjižnica koje su voljne sudjelovati u projektu Zelena knjižnica. Anketu su sastavili članovi Radne grupe za zelene knjižnice, a provedena je od veljače do travnja 2015. godine. Nakon analize rezultata zaključeno je da su knjižničari zainteresirani za umrežavanje u sklopu projekta Zelena knjižnica, da imaju razvijenu svijest o potrebi zaštite okoliša i želju da sudjeluju u oblikovanju tema vezanih uz zaštitu okoliša koje će predstaviti svojim korisnicima. ${ }^{25}$

U ovom radu prikazani su primjeri aktivnosti (predavanja i tribine o važnosti hodanja i planinarenja, o tjelesnom vježbanju djece predškolske dobi i o pravilnoj prehrani, likovne radionice i radionice izrade sapuna i sl.) koje su Knjižničarsko društvo Šibenik i Gradska knjižnica „Juraj Šižgorić“ Šibenik u posljednje dvije godine, točnije od 1. listopada 2016. do 1. listopada 2018., organizirali u okviru projekata Zelena knjižnica i Živjeti zdravo. Potonji projekt provodi se u suradnji sa Zavodom za javno zdravstvo Šibensko-kninske županije.

\section{Projekt Zelena knjižnica}

Aktivnosti u okviru projekta Zelena knjižnica u Gradskoj knjižnici „Juraj Šižgorić" Šibenik u posljednje dvije godine odnosile su se na radionice i predstavljanje knjiga. Radionica izrade sapuna, koju je vodila Ana Bebić, školska knjižničarka, polučila je izniman interes javnosti, zbog čega je radionica održana još dva-

23 43. skupština Hrvatskoga knjižničarskog društva. [citirano: 2018-10-25]. Dostupno na: http:// hkdrustvo.hr/hr/skupovi/skup/363/.

24 Grubišić Reiter, M. Zelena knjižnica u Knjižničarskom društvu Šibenik. // Glasnik društva bibliotekara Split 12-13(2014.-2015), 77-80.

25 Kraljević I.; P. Lukačić. Aktivnosti Radne grupe za Zelene knjižnice u 2015. godini. // HKD Novosti 69(2016). [citirano: 2018-10-25]. Dostupno na: https://www.hkdrustvo.hr/hkdnovosti/broj/66. 
put i u njoj je sudjelovalo ukupno 89 polaznika. Polaznici su naučili kako kod kuće na jednostavan način izraditi prirodne sapune, ljekovite meleme i eterična ulja. ${ }^{26}$ Godinu prije kolegica Bebić održala je radionicu izrade tradicionalnih biljnih i ljekovitih balzama i macerata, na kojoj su polaznici naučili kako kod kuće izraditi prirodni balzam za osobnu njegu, kao i unikatni poklon za predstojeće blagdane. ${ }^{27}$ Te su se radionice bavile 3. i 4. ciljem UN-ove Agende 2030.

Ekološke likovne radionice i natječaji koje vodi Zdenka Bilušić, voditeljica Odjela za vizualnu kulturu Knjižnice, inspirirani su Faustom Vrančićem i njegovim djelom Machine nove (prevedenim kao Novi strojevi). Radionice pod zajedničkim nazivom „Najnoviji novi strojevi“ imale su za temu tehničke izume i projekte Fausta Vrančića, što je također bila tema likovnih natječaja raspisivanih za učenike hrvatskih osnovnih i srednjih škola. Djeca su na osnovi Vrančićevih crteža kreirala vlastite, s prikazima različitih naprava koje donose „inovacije“ u rješavanju različitih ekoloških problema (npr. strojeva za čišćenje smeća, ekoloških vozila i sl.). Djeca su svoje „nove strojeve“ ilustrirala tušem i perom, naslikala akrilnim bojama na platnu ili oblikovala u prostoru, ostvarivši originalne, uvjerljive i neobične kompozicije. Svaki likovni uradak sadržavao je i naziv, kratak opis i namjenu izuma.

Radionice su se bavile 4., 7., 11., 12., 13., 14. i 15. ciljem UN-ove Agende 2030.

U zadnje dvije godine održano je osam radionica, koje je polazilo sedamdeset devet učenika. (U prilog velikom interesu za radionice govori i to da su na likovni natječaj koji se provodi nakon njih jedne godine prispjela čak 343 rada iz 43 osnove škole.)

Likovni radovi nastali na radionicama našli su svoje mjesto u virtualnom muzeju Fausta Vrančića na mrežnim stranicama Gradske knjižnice „Juraj Šižgorič“ Šibenik. Virtualni muzej dostupan je na http://faust.knjiznica-sibenik.hr. ${ }^{28}$

Likovne radionice koje je vodila Helena Šarić, učiteljica razredne nastave, također su imale za cilj ekološko osvještavanje učenika. Na tih deset radionica, koje su bavile ekologijom mora, sudjelovalo je sedam učenika osnovne škole, a njihovi radovi uvezani su u mapu. ${ }^{29}$ Radionice su se bavile 4. i 14. ciljem UN-ove Agende 2030.

\footnotetext{
26 Radionica o kućnoj izradi sapuna, ljekovitih melema i eteričnih ulja za osobnu ljepotu i zdravlje. // Arhiva događanja. [citirano: 2018-10-25]. Dostupno na: http://www.knjiznica-sibenik.hr/ arhiva_d.html.

27 Radionica izrade tradicionalnih biljnih i ljekovitih balzama i macerata. // Arhiva događanja. [citirano: 2018-10-25]. Dostupno na: http://www.knjiznica-sibenik.hr/arhiva_d.html.

28 Bilušić Z. Djelo Fausta Vrančića kao poticaj u dječjem likovnom izrazu. // Osvit 2(2017), 43-50.

29 Eko radionica "Podmorje". // Arhiva događanja. [citirano: 2018-10-25]. Dostupno na: http:// www.knjiznica-sibenik.hr/arhiva_d.html.
} 
U Knjižnici je predstavljeno nekoliko knjiga na temu zdrave prehrane: Zdravo $i$ slasno bez glutena Helene Jakoliš (za osobe koje imaju intoleranciju na neke namirnice $)^{30}$, Gurmanske veze Maje Petrovićsi ${ }^{31}$ U šumi - kako sam nadvladao autoimunu bolest uz pomoć paleo prehrane i funkcionalne medicine Denisa Delogua (intimna priča o vlastitom iskustvu autora kojemu je dijagnosticirana teška autoimuna bolest, multipla skleroza) ${ }^{32}$ i Velika knjiga o prehrani i njezi djece Sally Fallon Morell i Thomasa Cowan. ${ }^{33}$ Knjige su izašle u nakladničkoj kući Tragom, čija je vlasnica i urednica, nutricionistica Anita Šupe, na predstavljanjima s autorima razgovarala o zdravlju i pravilnoj prehrani odraslih i djece, ukazavši na zapanjujuću moć prehrane, odnosno važnost promjene prehrambenih i životnih navika. Izlaganja su bila vrlo dobro posjećena (174 posjetitelja). Posjetioci su mogli saznati koliko je pravilna prehrana važna za očuvanje zdravlja, sprečavanje pretilosti, smanjenje kardiovaskularnih i zaraznih bolesti i dijabetesa i sl. Ti ciljevi - poboljšana ishrana, sigurna hrana i osiguravanje zdrava života i blagostanja svih ljudi, uz društvenu pravdu i kvalitetno obrazovanje, koje uključuje i cjeloživotno učenje za sve - sadržani su i u 2., 3. i 4. cilju UN-ove Agende za održivi razvoj 2030.

Edukativna radionica o uporabi papira pod nazivom $3 R$ (Reduce, Reuse, Recycle), održana u suradnji s Javnom ustanovom „Nacionalni park Krka“"34, bila je namijenjena djeci predškolske dobi. Radionicu su vodile Doris Banić i Silvija Čaleta, zaposlenice Nacionalnog parka Krka, a u njoj je sudjelovalo dvadeset sedam polaznika. Osmišljena je na takav način da su kreativno iskorišteni materijali koji se inače svrstavaju u kategoriju otpada. Edukatori Nacionalnog parka „Krka“ govorili su djeci kroz jednostavne i praktične primjere o važnosti očuvanja prirode i okoliša. Izradili su perlice od sjajnog novinskog papira i napravili narukvice i ogrlice; PVC-vrećice iskoristili su za izradu velikih ružinih cvjetova koji mogu ukrašavati odjevni predmet ili torbu ili se mogu nositi kao narukvica; kućanskim glačalom na srednjoj temperaturi izglačali su PVC-vrećice i od njih izradili torbice za mobitel; u blenderu za kućanstvo reciklirali su matirani novinski papir, dodali mu različite bezopasne boje i od njega izradili različite predmete, ukrasili ih i

30 Predstavljanje knjige Zdravo i slasno bez glutena Helene Jakoliš. // Arhiva događanja. [citirano: 2018-10-25]. Dostupno na: http://www.knjiznica-sibenik.hr/arhiva_d.html.

31 Predstavljanje knjige Gurmanske veze Maje Petrović. // Arhiva događanja. [citirano: 2018-1025]. Dostupno na: http://www.knjiznica-sibenik.hr/arhiva_d.html.

32 Predstavljanje knjige U šumi — kako sam nadvladao autoimunu bolest uz pomoć paleo prehrane i funkcionalne medicine Denisa Delogua. // Arhiva događanja. [citirano: 2018-10-25]. Dostupno na: http://www.knjiznica-sibenik.hr/arhiva_d.html.

33 Predstavljanje Velike knjige o prehrani i njezi djece Sally Fallon Morell i Thomasa Cowana. // Arhiva događanja. [citirano: 2018-10-25]. Dostupno na: http://www.knjiznica-sibenik.hr/arhiva_d.html.

${ }_{34}$ Edukativna radionica 3R (Reduce, Reuse, Recycle) upotrebe papira. // Arhiva događanja. [citirano: 2018-10-25]. Dostupno na: http://www.knjiznica-sibenik.hr//arhiva_d.html. 
oslikali. Te su predmete poklonili djeci, koja su s velikim oduševljenjem aktivno sudjelovala u radionici, a dojmove su prenijela i svojim obiteljima, odgojiteljicama i, naravno, drugoj djeci u vrtićima. Da bi se djeca odgovorno ponašala prema prirodi u odrasloj dobi, vrlo je važno podučavati ih i ekološki osvještavati o važnosti procesa recikliranja od najranije životne dobi.

Ujesen 2017. održane su dvije edukativne radionice u dječjim vrtićima Osmijeh i Sunce o važnosti zaštite okoliša i očuvanja prirode, a vodila ih je Melinda Grubišić Reiter. Na njima je, da bi djeci dočarala kako zagađenje prirode uništava drveće, izvela eksperiment s celerom: stabljiku svježeg celera stavila je u čašu s vodom, u koju je dodala malo tinte, koja je „odglumila“ štetne tvari koje se šire vodom trujući celer, odnosno, u mašti, drvo. Kad je na koncu rasjekla celer, vidjelo se da se tinta popela uz stabljiku, što je zorno predočilo kako se štetan materijal širi u okolišu, konkretno u živom biću. Na radionicama su čitane i priče s tom tematikom. ${ }^{35}$ Djeca su naučila da treba štedjeti električnu energiju i vodu, skupljati stari papir, plastiku i staklo i odlagati ih u za to predviđene kontejnere. Djeca su pokazala veliko zanimanje i rado su sudjelovala u razgovoru. Rezultat tih radionica bilo je informiranje, educiranje i senzibiliziranje djece vrtićke dobi o potrebi zaštite i očuvanja čovjekova okoliša, što zadovoljava 4. i 15. cilj UN-ove Agende 2030., kao i u prethodnoj radionici. U radionicama je sudjelovalo četrdeset pet polaznika.

\section{Projekt Živjeti zdravo}

U ožujku 2018. godine u Šibeniku je održana 17. konferencija Nacionalnog programa Živjeti zdravo ${ }^{36}$, kojom je najavljen početak aktivnosti u okviru toga programa u Šibensko-kninskoj županiji. Konferenciju su organizirali Hrvatski zavod za javno zdravstvo i Zavod za javno zdravstvo Šibensko-kninske županije. Cilj Konferencije bilo je predstavljanje primjera dobre prakse promicanja zdravlja u Šibensko-kninskoj županiji kako bi se osnažile postojeće i potaknule nove aktivnosti te na taj način povezali najvažniji dionici u promicanju zdravlja na županijskoj i nacionalnoj razini. Na konferenciji je o iskustvima Knjižnice u provođenju sličnih projekata govorila Melinda Grubišić Reiter.

Zavod za javno zdravstvo Šibensko-kninske županije, prepoznavši dotadašnji rad Knjižnice, pozvao ju je da se kao partner pridruži provedbi toga projekta.

Povećanje udjela starijih osoba u ukupnoj populaciji, sjedilački način života i preveliko tjelesno opterećenje poslom te izloženost stresu i po zdravlje štetnim

35 Izvješće o radu Gradske knjižnice „Juraj Šižgorić“ Šibenik u 2017. godini. [citirano: 2018-1025]. Dostupno na: http:// www.knjiznica-sibenik.hr/dokum/Izvjesce o radu knjiznice u 2017. pdf.

36 U Šibeniku održana 17. konferencija Nacionalnog programa „Živjeti zdravo“. [citirano: 2018-10-25]. Dostupno na: http://sibensko-kninska-zupanija.hr/arhiva-novosti/u-ibeniku-odrana-17-konferencija-nacionalnog-programa-ivjeti-zdravo/2301.html. 
životnim navikama doveli su do velikog porasta bolesti i smrti u posljednjih nekoliko desetljeća. Zbog toga su Ministarstvo zdravlja i Hrvatski zavod za javno zdravstvo 2003. organizirali Nacionalni program Živjeti zdravo. Godine 2014. ponovno je pokrenuta provedba toga projekta s ciljem informiranja, senzibiliziranja i educiranja građana Republike Hrvatske o pozitivnom djelovanju zdravog načina života, pravilnoj prehrani, tjelesnoj aktivnosti, prevenciji debljine, smanjenju prekomjerne tjelesne mase i kardiovaskularnih bolesti, tumora, dijabetesa, plućnih i mentalnih bolesti. Projekt je svojim programima i aktivnostima usmjeren na poboljšanje zdravlja cijele populacije, a uključuje pet pojedinačnih projekata: Zdravstveno obrazovanje (projekt Poligoni, projekt 10' vježbanje, Preporučeni jelovnici za osnovne i srednje škole), Zdravlje i tjelesna aktivnost (projekt Hodanjem do zdravlja), Zdravlje i prehrana (jamstveni žig Živjeti zdravo, Program pravilne prehrane u školama), Zdravlje i radno mjesto (projekt Tvrtka prijatelj zdravlja) i Zdravlje i okoliš (projekt Volonteri u parku). ${ }^{37}$ Knjižnica je uočila važnost tih tema i mogućnosti koje ima kao ustanova, pa je organizirala različita događanja, predavanja i promocije da bi potaknula građane na pozitivne promjene u njihovu ponašanju i navikama.

\subsection{Programi projekta Živjeti zdravo}

Kako bismo potaknuli građane na kretanje i tjelesno vježbanje, promovirali smo rad i planove dvaju planinarskih društava koja djeluju u gradu Šibeniku. Hrvatsko planinarsko društvo Kamenar ${ }^{38}$, osnovano još 1926., koje okuplja uglavnom stariju populaciju, predstavilo se kratkim filmom o svim događanjima, izletima i pohodima društva u 2017. godini. (To društvo već šesnaest godina izdaje časopis Glasnik Kamenara, koji bilježi sve njegove aktivnosti.) Hrvatski planinarski klub sv. Mihovil ${ }^{39}$, koji većinom okuplja mlađu populaciju i čiji su planinari poznati po visokogorskom planinarenju po zahtjevnim europskim i svjetskim vrhovima (npr. na Aconcaguu visok $6950 \mathrm{~m}$ i Kilimanjaro visok $4900 \mathrm{~m}$ ), predstavio se predavanjem Što nam planine znače i predstavljanjem svih svojih sekcija: alpinističke, planinarske, speleološke i sportskog penjanja.

Na predavanjima koja su ta dva društva organizirala posjetitelji su mogli steći znanje o temama kao što su kvalitetno provođenje slobodnog vremena u prirodi, međusobno razmjenjivanje iskustava o zdravim načinima života, važnost zaštite

\footnotetext{
37 Živjeti zdravo. [citirano: 2018-10-25]. Dostupno na: https://www.hzjz.hr/sluzba-promicanjezdravlja/nacionalni-program-zivjeti-zdravo/2/.

38 Povijest društva. [citirano: 2018-10-25]. Dostupno na: http://www.hpd-kamenar.hr/o_nama. php.

39 Povijest Kluba. [citirano: 2018-10-25]. Dostupno na: http://www.sv-mihovil.hr/stranice/povijest-kluba/2.htm.
} 
okoliša i prirode te svijest o osobnoj odgovornosti u očuvanju okoliša. Na oba događanja bilo je ukupno 138 posjetitelja.

U multimedijskoj dvorani Gradske knjižnice „Juraj Šižgorić“ Šibenik magistar kineziologije Ivica Kljajić održao je predavanje „Važnost tjelesnog vježbanja u vrtićkoj dobi“, koje je izazvalo veliku pozornost roditelja. Roditelji su tako saznali da je važno plan i program vježbanja prilagoditi svakom djetetu i pritom uvažiti njihovu dob, osobine i sposobnosti. Učeći osnove raznih sportova dijete se može usmjeriti na treniranje onoga sporta za koji pokaže predispozicije. Rezultat Kljajićeva izlaganja bilo je to što su posjetitelji (njih 75) dobili informacije o važnosti tjelesne aktivnosti u očuvanju zdravlja djece. Naučili su i da se svakodnevnim tjelesnim aktivnostima (npr. desetominutnim vježbanjem) stvaraju zdrave životne navike, što je preduvjet dobrom funkcioniranju cijelog organizma. Predavanje se, kao i dva prethodna, bavilo 3. i 4. ciljem UN-ove agende 2030.

U Dječjem vrtiću Osmijeh tijekom travnja 2018. godine promovirano je poticanje zdravog načina života na način da su djeci čitane slikovnice i priručnici o zdravoj prehrani za njih. Na početku tih radionica djeca bi izvela nekoliko vježbi istezanja kako bi ih se naučilo da trebaju svakodnevno vježbati od najranije dobi. Djeca su rado razgovarala o svojim zdravim navikama, kao i o onima koje tek trebaju steći.

Početkom rujna 2018. godine održali smo radionicu za učenike 3. razreda osnovne škole. Krenuli smo s laganim vježbama pod nazivom Brain Gym (gimnastika za mozak) da bismo potaknuli bolju koncentraciju i opuštenost. Inače, to je temeljni senzomotorički program edukacijske kineziologije, koji uključuje aktivnosti i vježbe kojima se potiče integracija moždanih funkcija, integracija sustava uma i tijela, odnosno integrirano djelovanje cijeloga mozga i tijela u okvirima triju dimenzija (lateralnosti, centriranja i fokusiranja). ${ }^{40}$ Nakon toga, čitali smo priče o zdravoj hrani i razgovarali o ispravnim stilovima života, tjelesnom vježbanju i pravilnoj prehrani.

Ishod tih radionica, koje je pohađalo 75 predškolaca i 67 osnovnoškolaca razredne nastave, bilo je usmjeravanje djece prema usvajanju navika pravilne prehrane i tjelesne aktivnosti, kao i osvješćivanje o važnosti očuvanja tjelesnog i mentalnog zdravlja.

Takve su akcije korisne radi stjecanja novih znanja i kvalitetnijeg načina života od malih nogu. Akcije su ispunile 2., 3., 4. i 6. cilj UN-ove Agende.

Za srednjoškolce, i to učenike Medicinske škole Šibenik, održane su projekcije dokumentarnih filmova Priča o stvarima: priča o flaširanoj vodi i Sjeme slobode, koji govore o važnosti zdrave hrane. Na četirima projekcijama bila su 103 gledatelja. Priča o stvarima: priča o flaširanoj vodi: (The Story of Stuff: The Story of Bottled Water) iznosi uvriježeno mišljenje o izmišljenoj potrebi kupovanja vode

40 Brain gym. [citirano: 2018-10-25]. Dostupno na: https://www.edu-moveo.hr/brain-gym/. 
iz boce te podučava o tome kako prestati s tom lošom navikom. Sjeme slobode govori o malim ljudima koji generacijama čuvaju sjeme s vlastitih polja, koji obrađuju zemlju da bi prehranili svoju obitelj i lokalnu zajednicu, i o njihovoj borbi s velikim korporacijama koje proizvode genetski modificirano sjeme, a kojima je jedini interes zarada. U filmu je istaknuto pravo na očuvanje autohtonog sjemena i bioraznolikosti određenih područja, kao i uloga sjemena u tradiciji pojedinih kultura na svjetskoj razini. ${ }^{41}$

Srednjoškolci su stekli spoznaje o potrebi poboljšavanja ishrane, sigurnosti hrane i promoviranju održive poljoprivrede koja može svima pružiti zdravu hranu i donositi pristojne prihode te ujedno podržavati ljude usmjerene na ruralni razvoj i zaštitu okoliša, što je 1., 2. i 3. cilj UN-ove Agende. Tomu pripada i 6. cilj, koji govori o održivom upravljanju vodama i osiguravanju pristupa pitkoj vodi za sve. Zadovoljen je i 4. cilj, kojim se želi osigurati to da svi učenici steknu znanja i vještine potrebne za unapređivanje održivog razvoja kroz edukaciju za održivi razvoj i održive stilove života, ljudska prava, pripadnost globalnoj zajednici, poštivanje kulturne raznolikosti i doprinos kulturi održivog razvoja sve do kraja 2030. godine.

Projekciju filmova omogućila je Aktivistička grupa Zelena akcija odmah nakon završetka E?! - Okolišnog film festivala. Akciju je pokrenula Radna grupa za zelene knjižnice na nacionalnoj razini (Pokrenimo zelene knjižnice) u svibnju 2015 godine. $^{42}$

Nakon šibenske knjižnice, vrijednost projekta Živjeti zdravo prepoznala je i Nacionalna i sveučilišna knjižnica, koja se programu priključila tribinom na kojoj je projekt predstavljen. Maja Lang Morović, prof. rehabilitator, voditeljica Odsjeka za koordinaciju nacionalnih aktivnosti promicanja zdravlja pri Hrvatskome zavodu za javno zdravstvo, i dr. sc. Slaven Krtalić, prof. kineziologije, voditelj Odsjeka za tjelesnu aktivnost Službe za promicanje zdravlja Hrvatskoga zavoda za javno zdravstvo, prezentirali su projekt i izveli kratak program vježbi koje se mogu provoditi na radnome mjestu. Tribina je održana u sklopu programa Održive tribine Let’s Go Green! projekta Zelena knjižnica za zelenu Hrvatsku, u suradnji s Radnom grupom za zelene knjižnice Hrvatskoga knjižničarskog društva. ${ }^{43}$ Time je Nacionalna i sveučilišna knjižnica pokazala da je spremna sudjelovati u novim programima, od onih koji se bave očuvanjem zdravlja do onih koji tretiraju probleme očuvanja prirode i održivog razvoja.

41 3. nacionalna akcija „Pokrenimo zelene knjižnice“. [citirano: 2018-10-25]. Dostupno na: http://zk.dbi.hr/3-nacionalna-akcija-pokrenimo-zelene-knjiznice/.

${ }^{42}$ Nacionalna akcija „Pokrenimo zelene knjižnice“. [citirano: 2018-10-25]. Dostupno na: http:// www.hkdrustvo.hr/hr/novosti/odabrana_novost/803/?target=/hr/novosti/lista_novosti/150//.

43 Prva iz ciklusa održivih tribina u NSK - predstavljanje Nacionalnoga projekta „Živjeti zdravo“. [citirano: 2018-10-25]. Dostupno na: http://www.nsk.hr/prva-iz-ciklusa-odrzivih-tribina-u-nsk-predstavljanje-nacionalnoga-projekta-zivjeti-zdravo/. 


\section{Zaključak}

Knjižnice mogu znatno pridonijeti rješavanju problema održivog razvoja određene zajednice jer korisnicima omogućuju neposredan pristup svim vrstama znanja i informacija, a mogu organizirati i različite programe ili aktivnosti koje se tom tematikom bave. Pritom je važno privući što veći broj korisnika, kako bi kroz odabrane programe usvojili nove vrijednosti i obrasce ponašanja.

Za provedbu kvalitetnih i raznovrsnih programskih sadržaja s tematikom zdravog načina života, zaštite prirode i ekologije nužna je suradnja s različitim ustanovama i udrugama koje se profesionalno bave temama kao što su pravilna prehrana, kretanje, tjelovježba i očuvanje okoliša. Tu su osobito važne narodne knjižnice jer su one javno dostupni prostori otvoreni za korisnike svih dobnih skupina, a ispunjavaju potrebne uvjete: prostor, informacije i kontakte.

Programima koji pridonose zelenoj pismenosti knjižnice su se aktivno uključile u provedbu UN-ove Agende za održivi razvoj 2030.

Posjećenost radionica, predavanja, promocija i filmskih projekcija pokazala je da su korisnici, odnosno posjetitelji, vrlo zadovoljni raznolikošću i kvalitetom ponude. U posljednje dvije godine ta su dva projekta okupila 834 sudionika: na radionicama ih je bilo 344, na predavanjima 214, na predstavljanjima knjiga o zdravoj prehrani 173, a na filmskim projekcijama 103 - od toga 102 vrtićke dobi, 153 osnovnoškolca, 103 srednjoškolca i 476 odraslih. (Treba naglasiti da se projekt Živjeti zdravo u Knjižnici odvija tek šest mjeseci, tj. od travnja 2018.)

Aktivnosti koje je Knjižnica provela u sklopu projekata Živjeti zdravo i Zelena knjižnica pokazale su da kod korisnika postoji potreba da budu informirani o temama vezanim uz zaštitu okoliša i zdrav način života. Stoga je Knjižnica odlučila intenzivirati i proširiti te aktivnosti nizom predavanja, tribina i radionica, pa npr. planira organizirati ciklus predavanja za roditelje na kojima bi pedijatri specijalisti govorili o važnosti zdrave prehrane za smanjenje pretilosti i prevenciju različitih bolesti koje nastaju kao posljedica konzumiranja nezdrave prehrane.

Provest će se i radionice i predavanja za odrasle osobe, kao i one treće životne dobi, kako bismo i njima pokazali na koje sve načine mogu poboljšati kvalitetu života. Planirane su i tribine i predavanja o važnosti kretanja i tjelesnog vježbanja za djecu i odrasle, u suradnji sa sportskim udrugama, ali i s Javnom ustanovom „Nacionalni park Krka“, koja je vrlo aktivna u tretiranju ekoloških tema kroz izložbe, predavanja, filmove, tribine i radionice.

Kroz projekt Živjeti zdravo Knjižnica će se uključiti u provedbu 1., 2., 3., 4. i 6. cilja UN-ove Agende za održivi razvoj 2030, dakle zalagat će se za iskorjenjivanje gladi, sigurnost hrane i poboljšanu ishranu, promidžbu održive poljoprivrede, osiguravanje zdrava života i blagostanja svih ljudi, društvenu pravdu i kvalitetno obrazovanje, koje uključuje i cjeloživotno učenje za sve. 
Projekt Zelena knjižnica i dalje će uključivati predavanja, radionice, tribine i izložbe radi ostvarivanja 2., 3., 4., 11., 12., 13., 14. i 15. cilja UN-ove Agende za održivi razvoj 2030, koji traže sljedeće: učiniti gradove i naselja uključivim, sigurnim, prilagodljivim i održivim, osigurati održive oblike potrošnje i proizvodnje, poduzeti hitna djelovanja u borbi protiv klimatskih promjena i njihovih posljedica, očuvati i održivo koristiti oceane, mora i morske resurse za održivi razvoj, očuvati, ponovno uspostaviti i promicati održivo korištenje kopnenih ekosustava, održivo upravljati šumama, suzbiti dezertifikaciju, zaustaviti degradaciju tla te spriječiti uništavanje biološke raznolikosti, ojačati načine provedbe te učvrstiti globalno partnerstvo za održivi razvoj.

$\mathrm{Na}$ koncu treba istaknuti odličnu suradnju Knjižnice s ustanovama, udrugama i pojedincima u ostvarivanju tih projekata, kao i velik odaziv korisnika koji su prepoznali njihovu važnost kako na lokalnoj tako i na globalnoj razini.

\section{LITERATURA:}

Bilušić Z. Djelo Fausta Vrančića kao poticaj u dječjem likovnom izrazu. // Osvit 2(2017), 43-50.

Blewitt, J. Razumijevanje održivog razvoja. Zagreb: Naklada Jesenski i Turk, 2017.

Brain gym. [citirano: 2018-10-25]. Dostupno na: https://www.edu-moveo.hr/brain-gym/.

43. skupština Hrvatskoga knjižničarskog društva. [citirano: 2018-10-25]. Dostupno na: http://hkdrustvo.hr/hr/skupovi/skup/363/.

Dragaš, B. Zelene knjižnice za zelenu pismenost: hrvatsko iskustvo. // Vjesnik bibliotekara Hrvatske 60, 4(2017), 221-241. Dostupno i na: https://www.hkdrustvo.hr/vjesnik-bibliotekara-hrvatske/index.php/vbh/article/view/530. [citirano: 2018-10-25].

Edukativne radionice radionica 3R (Reduce, Reuse, Recycle) upotrebe papira. // Arhiva događanja. [citirano: 2018-10-25]. Dostupno na: http://www.knjiznica-sibenik.hr// arhiva_d.html.

Eko radionica „Podmorje“. // Arhiva događanja. [citirano: 2018-10-25]. Dostupno na: http://www.knjiznica-sibenik.hr/arhiva_d.html.

Gradska knjižnica „Juraj Šižgorić“. Arhiva događanja. [citirano: 2018-10-25]. Dostupno na: http://www.knjiznica-sibenik.hr/arhiva_d.html.

Grubišić Reiter, M. Zelena knjižnica u Knjižničarskom društvu Šibenik. // Glasnik društva bibliotekara Split 12-13(2014-2015), 77-80.

Herceg, N. Okoliš i održivi razvoj. Zagreb: Synopsis, 2013. 
IFLA statement on libraries and development. [citirano: 2018-10-25]. Dostupno na: http://www.ifla.org/publications/ifla-statement-on-libraries-and-development.

IFLA World Library and Information Congress. [citirano: 2018-10-25]. Dostupno na: https://2017.ifla.org/.

Izvješće o radu Gradske knjižnice „Juraj Šižgorić“ Šibenik u 2012. godini. [citirano: 2018-10-25].

Dostupno na: http://www.knjiznica-sibenik.hr/dokum/Izvjesce_o_radu_knjiznice_u_2012.pdf.

Izvješće o radu Gradske knjižnice „Juraj Šižgorić“ Šibenik u 2017. godini. [citirano: 2018-10-25]. Dostupno na: http:// www.knjiznica-sibenik.hr/dokum/Izvjesce o radu knjiznice u 2017. pdf.

Kraljević I.; P. Lukačić. Aktivnosti Radne grupe za Zelene knjižnice u 2015. godini. // HKD Novosti 69(2016). [citirano: 2018-10-25]. Dostupno na: https://www.hkdrustvo.hr/hkdnovosti/broj/66.

Kraljević, I. Zelena knjižnica: projekt Društva bibliotekara Istre. // Vjesnik bibliotekara Hrvatske 56, 3(2013), 199-204. Dostupno i na: https://www.hkdrustvo.hr/vjesnik-bibliotekara-hrvatske/index.php/vbh/article/view/170 [citirano: 2018-10-25].

Nacionalna akcija „Pokrenimo zelene knjižnice“. [citirano: 2018-10-25]. Dostupno na: http://www.hkdrustvo.hr/hr/novosti/odabrana_novost/803/?target=/hr/novosti/ lista_novosti/150//.

Novi izazov: globalni ciljevi održivog razvoja do 2030. Zagreb: ODRAZ, 2016. Dostupno i na: http://odraz.hr/media/291518/globalni\%20ciljevi\%20odrzivog\%20razvoja\%20do\%202030_web.pdf. [citirano: 2018-10-25].

Odluka o osnivanju Nacionalnog vijeća za održivi razvoj. // Narodne novine 7, 188(2018). [citirano: 2018-10-25]. Dostupno na: https://narodne- novine.nn.hr/clanci/sluzbeni/full/2018_01_7_188.html.

Održivi razvoj. [citirano: 2018-10-25]. Dostupno na: https://www.mzoip.hr/hr/klima/ odrzivi-razvoj.

15. okrugli stol o slobodnom pristupu informacijama „Knjižnice i održivi razvoj“. [citirano: 2018-10-25]. Dostupno na: http://www.nsk.hr/15-okrugli-stol-o-slobodnome-pristupu-informacijama-knjiznice-i-odrzivi-razvoj/.

Povijest društva. [citirano: 2018-10-25]. Dostupno na: http://www.hpd-kamenar.hr/o_ nama.php.

Povijest Kluba. [citirano: 2018-10-25]. Dostupno na: http://www.sv-mihovil.hr/stranice/povijest-kluba/2.htm.

Predstavljanje knjige Gurmanske veze Maje Petrović. // Arhiva događanja. [citirano: 2018-10-25]. Dostupno na: http://www.knjiznica-sibenik.hr/arhiva_d.html. 
Predstavljanje knjige $U$ šumi - kako sam nadvladao autoimunu bolest uz pomoć paleo prehrane i funkcionalne medicine Denisa Delogua. // Arhiva događanja. [citirano: 2018-10-25]. Dostupno na: http://www.knjiznica-sibenik.hr/arhiva_d.html.

Predstavljanje Velike knjige o prehrani i njezi djece Sally Fallon Morell i Thomasa Cowana. // Arhiva događanja. [citirano: 2018-10-25]. Dostupno na: http://www. knjiznica-sibenik.hr/arhiva_d.html.

Predstavljanje knjige Zdravo i slasno bez glutena Helene Jakoliš. // Arhiva događanja. [citirano: 2018-10-25]. Dostupno na: http://www.knjiznica-sibenik.hr/arhiva_d. $\mathrm{html}$.

Prva iz ciklusa održivih tribina u NSK - predstavljanje Nacionalnoga projekta „Živjeti zdravo". [citirano: 2018-10-25]. Dostupno na: http://www.nsk.hr/prva-iz-ciklusa-odrzivih-tribina-u-nsk-predstavljanje-nacionalnoga-projekta-zivjeti-zdravo/.

Radionica izrade tradicionalnih biljnih i ljekovitih balzama i macerata. // Arhiva događanja. [citirano: 2018-10-25]. Dostupno na: http://www.knjiznica-sibenik.hr/arhiva_d.html.

Radionica „Uloga knjižnica u provođenju UN-ove Agende 2030. i ciljeva održivog razvoja“" u NSK. [citirano: 2018-10-25]. Dostupno na: http://www.nsk.hr/radionica-uloga-knjiznica-u-provodenju-un-ove-agende-2030-i-ciljeva-odrzivog-razvoja-u-nsk/.

Radionica o kućnoj izradi sapuna, ljekovitih melema i eteričnih ulja za osobnu ljepotu i zdravlje. // Arhiva događanja. [citirano: 2018-10-25]. Dostupno na: http://www. knjiznica-sibenik.hr/arhiva_d.html.

Strategija održivog razvitka Republike Hrvatske. // Narodne novine 30, 658(2009). Dostupno i na: http://narodne-novine.nn.hr/clanci/sluzbeni/2009_03_30_658.html. [citirano:2018-10-25].

Svjetski knjižničarski i informacijski kongres i 83. generalna skupština IFLA-e. [citirano: 2018-10-25]. Dostupno na: http://www.nsk.hr/svjetski-knjiznicarski-i-informacijski-kongres-i-83-generalna-skupstina-ifla-e/.

3. nacionalna akcija „Pokrenimo zelene knjižnice“. [citirano: 2018-10-25]. Dostupno na: http://zk.dbi.hr/3-nacionalna-akcija-pokrenimo-zelene-knjiznice/.

U Šibeniku održana 17. konferencija Nacionalnog programa „Živjeti zdravo“. [citirano: 2018-10-25]. Dostupno na: http://sibensko-kninska-zupanija.hr/arhiva-novosti/u-sibeniku-odrzana-17-konferencija-nacionalnog-programa-zivjeti-zdravo/2301.html.

UNESCO-ov manifest za narodne knjižnice. [citirano: 2018-10-25]. Dostupno na: http://dzs.ffzg.unizg.hr/text/UNESCOv_manifest_za_narodne_knjiznice.htm.

Živjeti zdravo. [citirano: 2018-10-25]. Dostupno na: https://www.hzjz.hr/sluzba-promicanje-zdravlja/nacionalni-program-zivjeti-zdravo/2/. 